\title{
The coexistence of pituitary macroadenoma and schizophrenia - practical therapeutic implications based on the case report and the literature review
}

\author{
Wspótwystępowanie makrogruczolaka przysadki i schizofrenii - praktyczne \\ implikacje terapeutyczne na podstawie opisu przypadku i przeglądu literatury
}

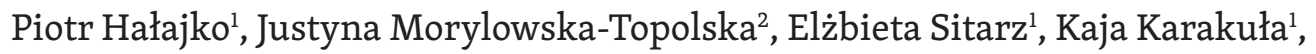
Alicja Forma ${ }^{3}$, Hanna Karakuła-Juchnowicz ${ }^{1}$

1 I Department of Psychiatry, Psychotherapy, and Early Intervention, Medical University of Lublin, Poland

2 Department of Clinical Neuropsychiatry, Medical University of Lublin, Poland

3 Chair and Department of Forensic Medicine, Medical University of Lublin, Poland

\section{ABSTRACT}

Introduction. Antipsychotic drugs may increase serum prolactin levels. This effect is the strongest in patients treated with risperidone and amisulpride.

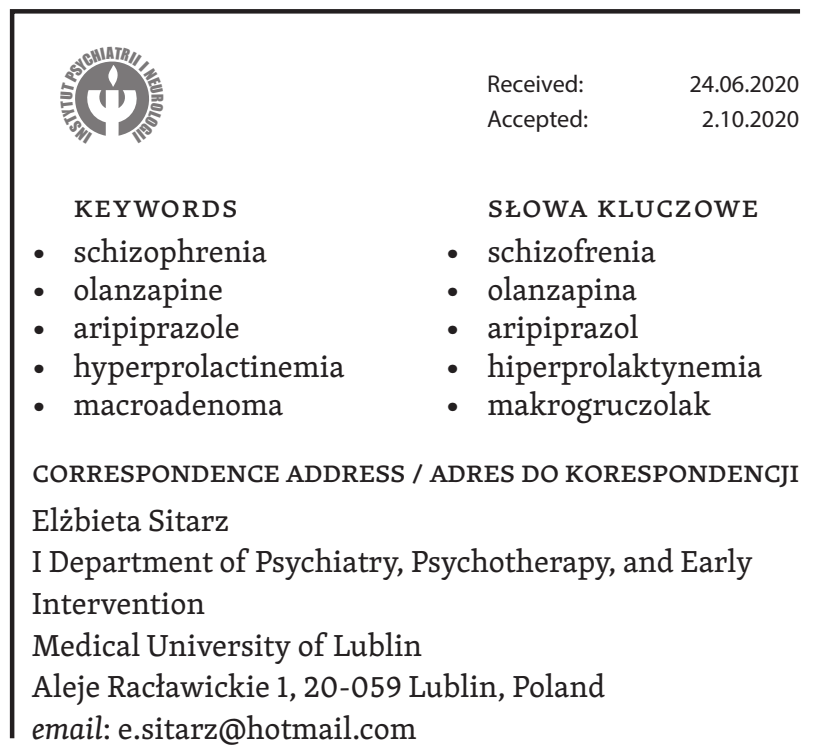

Aim. This paper (1) presents a case report of an active pituitary macroadenoma diagnosed in a patient receiving a long-term olanzapine treatment; and (2) discusses its practical therapeutic implications based on the literature review.

Case report. A 28-year-old male patient had been treated with olanzapine for paranoid schizophrenia since 2008. In December 2016, an unsuccessful attempt to discontinue the drug was made as the patient had been in remission for the past few years. The attempt ended in March 2017 with psychiatric hospitalisation. MRI of the head and a prolactin test revealed a pituitary macroadenoma. The medication was changed from olanzapine to aripiprazole, but the patient's mental status deteriorated. Ziprasidone was initiated, which resulted in symptomatic remission. The MRI scans of the head that were made in the following months showed no tumour progression. As prolactin levels were stably high, the patient received quinagolide therapy. In addition, small doses of clozapine and psychotherapy were added to the ongoing treatment. Conclusions. The present case report shows that (1) routine imaging tests should be performed as part of the diagnostic procedure in first-episode psychosis; 
(2) prolactin levels should be measured both before and during therapy; and (3) early and close interdisciplinary cooperation is needed to develop common therapeutic recommendations that could be applied in difficult and non-typical clinical cases, such as the one described herein.

\section{STRESZCZENIE}

Wstęp. Leki przeciwpsychotyczne mogą powodować wzrost stężenia prolaktyny w surowicy, a najsilniejszy wpływ w tym zakresie obserwuje się w trakcie leczenia risperidonem i amisulprydem. Istnieją doniesienia wskazujące na moźliwość indukcji guza przysadki przez długotrwałe przyjmowanie risperidonu.

Cel. Celem pracy jest przedstawienie: 1) opisu pacjenta, u którego w trakcie wieloletniego leczenia olanzapiną rozpoznano czynnego makrogruczolaka przysadki, 2) praktycznych implikacji terapeutycznych na podstawie przeglądu literatury dotyczącej tej tematyki.

Opis przypadku. Pacjent, lat 28 , leczony z powodu schizofrenii paranoidalnej olanzapiną od 2008 roku. W związku z uzyskaniem długoletniej remisji, w grudniu 2016 roku podjęto nieudaną próbę odstawienia leku, która skończyła się w marcu 2017 roku hospitalizacją

\section{Introduction}

Pharmacotherapy with antipsychotic drugs often leads to an increase in serum prolactin levels (Szarfman et al., 2006), which is associated with the antagonistic effects of these drugs on D2 receptors (Stahl, 2009). Prolactin levels are most strongly affected during treatment with risperidone and amisulpride (Szarfman et al., 2006; Kahn et al., 2008). Additionally, there is evidence from animal models that risperidone can induce pituitary tumours (FDA, 2009). The impact of the use of other second-generation antipsychotics on the occurrence of pituitary tumours in humans has not been thoroughly studied yet (Szarfman et al., 2006; FDA, 2009).

Pharmacotherapy is the treatment of choice for a prolactinoma (Chanson \& Maiter, 2019). Standard medications include ergot-derived dopamine D2 agonists, i.e. bromocriptine, lisuride, and cabergoline, as well as the non-ergot-derived dopamine agonist quinagolide (Syrenicz, 2009). Long-term pharmacotherapy is required and its effectiveness, depending on the drug used, can be as high as $>91.7 \%$, regardless of the tumour size (Berinder et al., 2005; Chanson \& Maiter, 2019). Pharmacotherapy is generally well tolerated by patients (Webster et al., 1994). Reports suggest that long-term treatment with cabergoline in combination with mirtazapine and quetiapine in a patient with a pituitary adenoma associated with psychotic disorders has resulted in a significant psychiatryczną. Wykonane badania: rezonans magnetyczny głowy (MRI) oraz stężenia prolaktyny wskazywały na występowanie makrogruczolaka przysadki. Dokonano zmiany farmakoterapii z olanzapiny na aripiprazol, jednak stan psychiczny uległ pogorszeniu. Nie zdecydowano się na proponowaną przez endokrynologa terapię bromokryptyną ze względu na występowanie nasilonych objawów psychotycznych. Pacjent odmówił leczenia operacyjnego. Do terapii włączono ziprasidon, co wiązało się z uzyskaniem remisji objawowej. W kolejnych miesiącach wykonywano badania MRI głowy, w których obserwowano brak progresji guza. Stężenie prolaktyny utrzymywało się na stałym wysokim poziomie, co było podstawą terapii chinagolidem. Dodatkowo do leczenia włączono niewielkie dawki klozapiny i oddziaływania psychoterapeutyczne.

Wnioski. Powyższy przypadek pokazuje potrzebę: 1) przeprowadzania rutynowych badań obrazowych w ramach procedur diagnostycznych i epizodu psychotycznego, 2) dokonywania pomiaru stężenia prolaktyny przed terapią, jak i w jej trakcie, 3) wczesnej i ścisłej współpracy interdyscyplinarnej w celu wypracowania wspólnej propozycji terapeutycznej w tak trudnych i nietypowych sytuacjach klinicznych.

reduction of the adenoma. The level of prolactin during treatment ranged from $14.992 \mathrm{ng} / \mathrm{ml}-1754 \mathrm{ng} / \mathrm{ml}$. In this case, surgery was inadvisable (Casulari et al., 2019).

Surgical treatment is most often pursued in emergency cases with significant tumour progression or tumour bleeding; nevertheless, planned surgeries are also performed in patients with prolactinomas, in whom pharmacotherapy is not effective, and in patients with other adenomas with symptoms of mass effect and hyperprolactinemia. Recurrence rates in surgically treated patients are $18.2 \%$ for microadenomas and $22.8 \%$ for macroadenomas (Gillam et al., 2006). In the event of incomplete tumour resection or tumour recurrence, surgical treatment can be supplemented with conventional radiotherapy, which extends the remission period (Becker et al., 2002; Ayuk \& Stewart, 2009). Other forms of therapy are stereotactic radiosurgery and fractionated stereotactic radiotherapy. Stereotactic radiosurgery allows to effectively control the tumour growth in $90 \%$ of patients; $44.7 \%$ of patients were reported to be in remission eight years after surgery (Laws et at., 2004; Castinetti et al., 2009). Both therapies show comparable effectiveness and safety (Li et al., 2017); however, they may inhibit the secretory function of the pituitary gland (Becker et al., 2002; Castinetti et al., 2009; Li et al., 2017). The main problem in schizophrenia patients with a prolactinoma is that they are treated with antipsychotic drugs, which, being dopaminergic antagonists, increase the activity of 
the tumour. Treatment of the pituitary adenoma with dopamine agonists is also problematic in these patients because these drugs may induce or aggravate psychosis or suppress the effectiveness of antipsychotic drugs (Melkersson \& Hulting, 2000; Broekhof et al., 2012).

\section{Aim}

The objective of this study is (1) to present the case report of an active pituitary macroadenoma diagnosed in a patient receiving long-term olanzapine treatment; and (2) to discuss the practical therapeutic implications based on a review of the literature.

\section{Case report}

In March 2017, a 28-year-old man was admitted to the Psychiatric Ward because of a sudden deterioration in his mental health. Since 2008, the patient had been receiving regular outpatient treatment with olanzapine for paranoid schizophrenia. No laboratory tests or head imaging scans had been performed before or during treatment. In December 2016, antipsychotic treatment had been discontinued due to the long-term symptomatic remission.

During hospitalisation (27 March 2017 - 29 June 2017), the patient was once again placed on a regimen of $10 \mathrm{mg}$ olanzapine/day (27 March 2017 - 23 April 2017), which improved his condition. MRI of the head (13 April 2017) showed a $21 \times 18 \times 18 \mathrm{~mm}$ lesion asymmetrically enlarging the sella turcica, which extended towards the left cavernous sinus with signs of infiltration, indicating the presence of a pituitary macroadenoma (Fig. 1). At the same time, the patient's serum prolactin level exceeded $2000 \mathrm{ng} / \mathrm{ml}$ (18 April 2017) (precise determination was not possible). When asked about the onset of hyperprolactinemia symptoms, the patient dated them back to the time of the initiation of antipsychotic treatment.

The patient was immediately switched to aripiprazole at a maximum dose of $30 \mathrm{mg} /$ day (20 April 2017 8 June 2017), which decreased his prolactin levels (to $753.95 \mathrm{ng} / \mathrm{ml}$ ) (8 May 2017), but at the same time caused a deterioration in his mental status. The patient refused surgical treatment recommended by the consulting neurosurgeon. Endocrinologist suggested that the patient should be treated with bromocriptine, but this recommendation was not followed due to the anticipated negative impact of this drug on the patient's mental condition. The patient was put on a regimen of ziprasidone (15 May 2017 - 29 June 2017) at a daily dose of $160 \mathrm{mg}$ and mirtazapine (2 June 2017 - 29 June 2017) at a daily dose of $15 \mathrm{mg}$, which resulted in an improvement in his mental health and a decrease in the prolactin level to $1459.52 \mathrm{ng} / \mathrm{ml}$ (26 June 2017). The endocrinologist decided to treat the patient with quinagolide, initially at a dose of $50 \mathrm{mg}$, then $75 \mathrm{mg}$ daily. An increase of the dose exacerbated the psychotic symptoms; the minimum dose was used every other day, which resulted in a further slight decrease in prolactin levels.

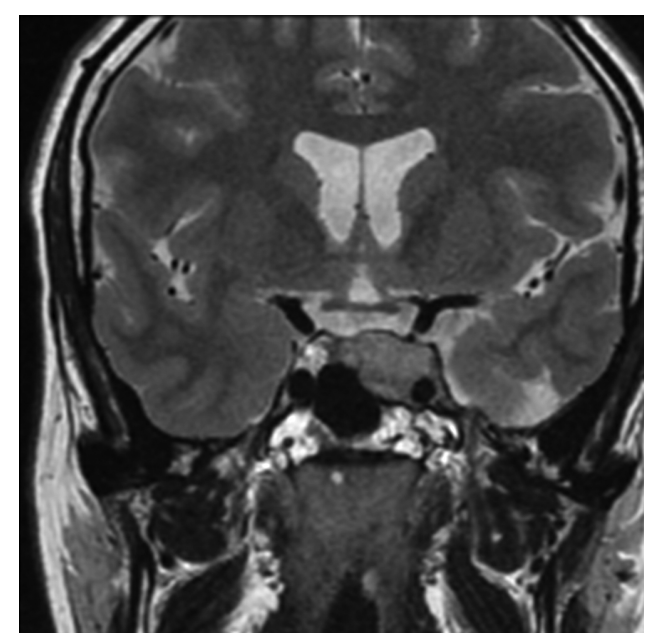

Figure 1 The pituitary gland on the left is associated with a solid, pathological mass with dimensions $21 \times 18 \times 18 \mathrm{~mm}$, widening the sella turcica asymmetrically, extending towards the left cavernous sinus. There is no compression on the optic chiasm and optic nerves in the intracranial segment. MRI T-2 weighted scan suggests pituitary macroadenoma

In April 2018, control MRI of the head was performed, which showed a slight reduction in the size of the adeno$\mathrm{ma}(21 \times 18 \times 15 \mathrm{~mm})$. The prolactin level was maintained at approx. $1250 \mathrm{ng} / \mathrm{ml}$. In June 2018, the patient complained of a feeling of internal tension and trouble falling asleep, and reported having some psychotic experiences in the previous few months. A decision was made to continue the current treatment, add a low tolerated dose of clozapine (50 mg), and to start cognitive-behavioural psychotherapy, which brought positive therapeutic effects. In January 2019, follow-up prolactin tests and MRI scans of the head were made, which respectively showed a further slight decrease in the prolactin level $(715 \mathrm{ng} / \mathrm{ml})$ and no changes as compared to the previous MRI findings.

\section{Discussion}

The aim of the present case report is to discuss important problems related to the diagnosis and therapy of patients with psychotic disorders and a co-morbid pituitary macroadenoma.

\section{The need for routine imaging in patients with first- episode psychosis}

Although the number of serious abnormalities detected using routine brain imaging is low ( $0 \%$ to $1 \%$ ) (Williams et al., 2014), the identification of lesions is crucial for 
optimal medical management (Karakuła-Juchnowicz et al., 2018). Currently, there is no consensus on whether imaging should be part of the routine care in patients with a first psychotic episode.

According to a systematic review conducted by Forbes et al. (2019), there is no evidence that brain imaging should be performed as a routine diagnostic test in a first psychotic episode unless co-morbid neurological or cognitive conditions are present. Diagnosis of damage to the central nervous system should be based on the analysis of the patients' disease and assessment of their mental and neurological condition. If an intracranial pathology is suspected, MRI or computed tomography (CT) should be performed. In other cases, evidence-based national guidelines should be followed (Forbes et al., 2019).

The guidelines of the American Psychiatric Association for the treatment of patients with schizophrenia (APA, 2010) state that MRI or CT scans performed in patients with a first psychotic episode or an atypical clinical picture can provide information that can be used to make a more precise diagnosis, establish treatment, and predict the prognosis. Given the subtlety of the neuropathological changes in schizophrenia, MRI is a better choice than CT (APA 2010).

The Australian Clinical Guidelines for Early Psychosis (Orygen, the National Centre of Excellence in Youth Mental Health, 2016) recommends that MRI be performed in all patients with a first psychotic episode (Orygen 2016).

According to the Royal Australian and New Zealand College of Psychiatrists Clinical Practice guidelines for the management of schizophrenia and related disorders, experts' opinions on the validity of performing neuroimaging in patients with the first episode of psychosis are divided (Galletly et al., 2016).

National Institute for Health and Care guidelines on structural neuroimaging in first-episode psychosis (NICE, 2011) do not recommend the use of structural neuroimaging techniques as a routine part of the initial investigations in the treatment of first-episode psychosis (NICE 2011).

Canadian Guidelines for the Assessment and Diagnosis of Patients with Schizophrenia Spectrum and Other Psychotic Disorders state that neuroimaging is indicated in cases when additional abnormalities have been found in neurological and neuropsychological examinations and should be ordered based on specific aspects of the patient's medical history (Addington et al., 2017).

For several years now, the cost of imaging tests in Poland has been relatively low (Agencja, 2016); therefore, it seems reasonable to consider their routine use in patients with first-episode psychosis.

In the case of the patient described in this report, MRI of the head performed at the time of initiation of antipsychotic treatment would have enabled early diagnosis of the pathological changes in the pituitary gland, assuming that this process had begun before the onset of psychotic symptoms. If the tumour developed later, the MRI findings could have been used as a reference for the follow-up scans.

\section{The need for periodic testing of prolactin levels in patients receiving antipsychotic treatment}

Tumours of the pituitary gland and the area of the sella turcica constitute about $15 \%$ of intracranial tumours in adults (Syrenicz, 2009; Mete \& Lopes, 2017). Most of them are benign adenomas with a mild course and slow growth dynamics (Petersenn, 2019). Pituitary carcinoma is a very rare primary finding and accounts for $0.2 \%$ of pituitary tumours (Molitch, 2017). Pituitary adenomas are divided by size, hormonal activity, and immunohistochemical staining results (Molitch, 2017). Hormonally active tumours are more common than inactive tumours; they are the most common cause of hyperpituitarism (Maitra, 2014; Mehta \& Lonser, 2017). Prolactinoma is the most prevalent type of pituitary adenoma ( $40 \%$ to $57 \%$ of cases) (Daly et al., 2006; Fernandez, 2010 et al.; Lake et al., 2013). Signs and symptoms are either due to the mass effect (the effect of the size of the tumour itself) or hyperprolactinemia (Hardy \& Czepko, 1999; Maitra, 2014; Chanson \& Maiter, 2019). Hyperprolactinemia can cause menstrual disorders, galactorrhea, decreased libido and infertility in women, as well as decreased libido, gynecomastia, erectile dysfunction, and hypogonadism in men. In both sexes, it leads to a decrease in bone mass and is a risk factor for osteoporosis (Matsuyama et al., 2003). An abnormally high prolactin level also affects the patients' mental well-being, causing anxiety, tension, or depression (Syrenicz, 2009; Liao \& Bai, 2014). The coexistence of a pituitary adenoma in a patient with psychotic disorders requires special attention. In such cases, meticulous monitoring of laboratory tests and careful control of prolactin levels in accordance with the recommendations for the use of antipsychotics seems indispensable.

According to the recommendations of the National Psychiatry Consultant on the use of second-generation antipsychotics (Zalecenia, 2012), the use of amisulpride and risperidone in the treatment of psychotic disorders requires regular prolactin monitoring. Before any antipsychotic is started, the patient should be carefully screened using the following laboratory tests: a complete blood count, aspartate transaminase and alanine transaminase activities, bilirubin, creatinine, electrolyte, and fasting blood sugar levels, and a fasting lipid profile. Only in justified cases are patients recommended to have their prolactin and thyroid hormone tests (TSH, FT4) done before the treatment is initiated.

In their daily clinical practice, physicians need to remember to take a careful history regarding hyperprolactinemia and to keep medical records with detailed information on laboratory data, especially when they 
administer drugs that affect the tuberoinfundibular pathway. Failure to do so may have serious consequences for the patient's health and life. In the case reported here, the patient had not had any blood tests done (including prolactin levels) during the eight years of outpatient treatment with olanzapine. One of the likely scenarios is that the patient had had persistently high serum prolactin levels, which had probably contributed to the development of pituitary macroadenoma. Olanzapine is an antipsychotic drug that does not significantly affect serum prolactin levels, although cases have been reported in which symptoms related to elevated serum prolactin levels appeared after starting olanzapine treatment (Barata et al., 2019).

It is difficult to determine, without prolactin tests, at what point the hyperprolactinemia started in the patient described in this report, although it can be concluded from the patient's history of sexual side effects that it occurred after the patient had been placed on the olanzapine regimen. A causal relationship between the long-term olanzapine treatment and the development of the pituitary macroadenoma can be neither confirmed nor excluded. Nevertheless, had greater vigilance been exercised in assessing the side effects and had periodic prolactin monitoring been ordered, the hormonally active pituitary tumour could have been diagnosed earlier and an appropriate change in the antipsychotic therapy could have been made.

\section{Choosing the safest therapy in patients with psychotic disorders comorbid with active pituitary macroadenoma}

A prolactin-secreting pituitary adenoma is the most common pituitary tumour (Lake et al., 2013). It is treated with dopamine agonists, which can cause psychotic symptoms as a side effect. On the other hand, the use of antipsychotic drugs may be associated with elevated serum prolactin levels and symptomatic hyperprolactinemia (Ali et al., 2010). Such co-occurrence of disorders leads to therapeutic difficulties and requires skilful selection of treatment strategies. An alternative to pharmacological therapy is the surgical removal of the pituitary adenoma (Mehta \& Lonser, 2017). When the treatment with dopamine agonists and surgery do not suffice to stabilise the tumour mass, radiation therapy may be considered. However, it is only reserved for aggressive tumours because it can lead to hypopituitarism. Moreover, radiation therapy does not satisfactorily normalise serum prolactin levels (Li et al., 2017).

In the case of a patient who has both symptoms of schizophrenia and a hormonally active pituitary adeno$\mathrm{ma}$, therapeutic decisions should be taken by a medical team consisting of a psychiatrist, an endocrinologist, and a neurologist or a neurosurgeon. The location, endocrine consequences, and the mass effect of the tumour should all be taken into account. The size and effect of the tumour mass may be decisive factors when considering surgery (Mehta \& Lonser, 2017). Dopamine agonists are not recommended for patients who have psychotic disorders because they pose a risk of psychiatric decompensation (Robbins et al., 1984). For tumours that do not exhibit the mass effect, management may consist of steroid hormones and closely monitoring the size of the adenoma (Miller, 2004). This type of management is suitable for patients with pituitary microadenomas (Vallette et al., 2009). A dopamine agonist may be tried if the patient also receives an antipsychotic, but this is not sufficient protection against psychiatric decompensation. There have been reports of psychotic symptoms due to the use of dopamine agonists in combination with antipsychotic drugs (Robbins et al., 1984).

The profile of the antipsychotic is an important aspect to be considered when starting drug therapy. All antipsychotics may to some extent affect serum prolactin levels (Chen et al., 2009). Those that significantly increase the prolactin concentration during treatment include typical antipsychotics and risperidone. Clozapine, olanzapine, quetiapine, aripiprazole, and ziprasidone have a lower potential to induce hyperprolactinemia (Byerly et al., 2007; Samperi et al., 2019). Clozapine at doses between 125 and $600 \mathrm{mg}$ shows 20 to $67 \%$ D2 receptor saturation. This result is synonymous with D2 receptor occupancy below the threshold above which the drug causes symptoms of hyperprolactinemia. On this basis, it can be expected that the use of clozapine is associated with a lower risk of increasing serum prolactin levels (Farah, 2013). The literature of the subject mentions two antipsychotics that do not affect or minimally affect prolactin levels aripiprazole and ziprasidone (Szarfman et al., 2006). Most of these reports regard the use of aripiprazole in similar clinical cases (Freeman et al., 2007; Steinhagen, 2007; Bakker et al., 2016). For example, in a study by Broekhof, a switch in therapy from risperidone to aripiprazole with simultaneous administration of cabergoline resulted in remission of schizophrenia, reduction of the tumour mass, and normalisation of prolactin levels. Given this finding, our patient was initially treated with aripiprazole. However, his mental status deteriorated. To date, several dozen cases of mental deterioration following initiation of aripiprazole have been reported (Grover et al., 2006; Ahuja \& Lloyd, 2007; Takeuchi \& Remington, 2013; Eatt \& Varghese, 2014). This risk is possibly related to the agonist/antagonist effect of this drug on D2 receptors (Stahl, 2009; Takeuchi \& Remington, 2013). Despite the improvement in hormonal parameters, the patient's mental status worsened. Therefore, aripiprazole was discontinued, and ziprasidone was initiated, which led to an improvement in the patient's mental well-being. Prolactin levels remained high, which could have had an additional impact on the patient's mental status (Syrenicz, 2009; Liao \& Bai, 2014). 
When considering the use of dopamine agonists, attention should be paid to the Melkersson's study (2000), which provides evidence that quinagolide crosses the blood-brain barrier to a lesser extent than bromocriptine and so should have a pronounced impact on the pituitary, but less influence on the mental status. Bromocriptine, on the other hand, has a more unselective receptor profile than quinagolide, which is why the latter, being a relatively selective $\mathrm{D} 2$ receptor agonist, might be a better treatment option for a patient with a pituitary adenoma who also has psychotic disorders. In the present case, bromocriptine was not administered because the patient had severe psychotic symptoms. Later, quinagolide was added to the patient's regimen at low, tolerated doses.

It seems that in this type of patients, surgical intervention (which was recommended by the consulting neurosurgeon) could be the treatment of choice. However, the patient did not agree to the surgery. The patient's decision certainly was partly associated with his mental status. On the other hand, with a tumour this size, the

\section{Wstęp}

Farmakoterapia lekami przeciwpsychotycznymi często powoduje wzrost stężenia prolaktyny w surowicy krwi (Szarfman i wsp., 2006), co jest związane z antagonistycznym wpływem na receptory D2 (Stahl, 2009). Najsilniejszy wpływ na stężenie prolaktyny obserwuje się w czasie leczenia risperidonem $i$ amisulpirydem (Szarfman i wsp., 2006; Kahn i wsp., 2008). Dodatkowo istnieją przesłanki wskazujące na możliwość indukcji guza przysadki przez risperidon, co zostało dowiedzione na modelu zwierzęcym (FDA, 2009). Wpływ stosowania innych leków przeciwpsychotycznych II generacji na występowanie guzów przysadki u ludzi nie został do tej pory dostatecznie zbadany (Szarfman i wsp., 2006; FDA, 2009).

Leczeniem z wyboru w przypadku guza prolaktynowego jest farmakoterapia (Chanson i Maiter, 2019). Stosuje się w niej zarówno agonistów receptorów dopaminowych D2, pochodne sporyszu: bromokryptynę, lizuryd, kabergolinę, jak i niesporyszowego agonistę dopaminy - chinagolid (Syrenicz, 2009). Wymagany jest wieloletni okres farmakoterapii, a jej skuteczność w zależności od stosowanego leku jest oceniana nawet na $>91,7 \%$, niezależnie od wielkości guza (Berinder i wsp., 2005; Chanson i Maiter, 2019). Sama farmakoterapia jest dobrze tolerowana przez pacjentów (Webster i wsp., 1994). Istnieją doniesienia sugerujące, że leczenie zachowawcze długotrwałym stosowaniem kabergoliny w połączeniu z mirtazapiną i kwetiapiną u pacjenta z gruczolakiem przysadki współwystępującym z zaburzeniami risk of recurrence after surgical intervention is high and resection does not guarantee a therapeutic success (Castinetti et al., 2009; Farah, 2013). Ultimately, a decision was made to place the patient on a regimen of low, tolerated doses of clozapine and psychotherapy, which led to good remission of the mental illness.

\section{Conclusions}

This case report indicates the need for:

1) routine imaging tests to be performed as part of the diagnostic procedure in first-episode psychosis;

2) systematic testing of plasma prolactin levels not only during pharmacotherapy with risperidone and amisulpride, but also during treatment with other second-generation antipsychotics; and

3) early and close interdisciplinary cooperation in developing a common therapeutic recommendations in such difficult and non-typical clinical cases as the one described in this paper.

psychotycznymi, przyczyniło się do znacznego zmniejszenia gruczolaka. Stężenie prolaktyny podczas leczenia wahało się w zakresie 14,992-1754 ng/ml. W tym przypadku zabieg chirurgiczny był niewskazany (Casulari i wsp., 2019).

Metody operacyjne stosuje się najczęściej w trybie pilnym, przy znacznej progresji guza czy krwawienia do guza, ale też w trybie planowym przy braku skuteczności farmakoterapii w guzach prolaktynowych oraz objawach efektu masy i czynności hormonalnej w przypadku pozostałych gruczolaków. Nawrotowość po operacji mikrogruczolaków wynosi 18,2\%, a makrogruczolaków - 22,8\% (Gillam i wsp., 2006). W razie niedoszczętnej resekcji guza lub nawrotu możliwe jest uzupełnienie leczenia o konwencjonalną radioterapię, która wydłuża okres remisji (Becker i wsp., 2002; Ayuk i Stewart 2009). Kolejnymi formami terapii są radiochirurgia stereotaktyczna lub frakcjonowana stereotaktyczna radioterapia. Stosując radiochirurgię stereotaktyczną, uzyskiwano kontrolę wzrostu guza u $90 \%$, a po 8 latach po zabiegu $44,7 \%$ pacjentów była w remisji (Laws i wsp., 2004; Castinetti i wsp., 2009). Obie terapie mają porównywalną skuteczność i bezpieczeństwo (Li i wsp., 2017). Powyższe metody radioterapii mogą jednak pogarszać czynność wydzielniczą (Becker i wsp., 2002; Castinetti i wsp., 2009; Li i wsp., 2017). U pacjentów z rozpoznaniem schizofrenii, u których wykryto guz prolaktynowy, zasadniczym problemem jest farmakoterapia lekami przeciwpsychotycznymi, które będąc antagonistami dopaminergicznymi, powodują wzrost aktywności gruczolaka prolaktynowego. Problematyczne jest również prowadzenie leczenia 
gruczolaka przysadki agonistami dopaminy, które może indukować lub nasilać psychozę, czy znosić skuteczność leków przeciwpsychotycznych (Melkersson i Hulting, 2000; Broekhof i wsp., 2012).

\section{Cel}

Celem pracy jest przedstawienie: 1) przypadku pacjenta, u którego w trakcie wieloletniego leczenia olanzapiną rozpoznano czynnego makrogruczolaka przysadki, 2) praktycznych implikacji terapeutycznych na podstawie przeglądu literatury dotyczącej tej tematyki.

\section{Opis przypadku}

W marcu 2017 roku 28-letni mężczyzna został przyjęty do Oddziału Psychiatrycznego, gdzie trafił z powodu nagłego pogorszenia stanu psychicznego. Od 2008 roku pacjent był systematycznie leczony w warunkach ambulatoryjnych olanzapiną z powodu schizofrenii paranoidalnej. Ani przed rozpoczęciem leczenia, ani w trakcie jego trwania nie wykonywano żadnych badań laboratoryjnych i obrazowych głowy. W grudniu 2016 roku zdecydowano o odstawieniu leczenia przeciwpsychotycznego z powodu utrzymującej się remisji objawowej.

W trakcie hospitalizacji (27.03.2017-29.06.2017 r.) ponownie włączono do leczenia olanzapinę (27.03.201723.04.2017 r.) w dawce $10 \mathrm{mg} /$ dobę uzyskując poprawę stanu pacjenta. W wykonanym badaniu MRI głowy (13.04.2017 r.), uwidoczniono w okolicy przysadki mózgowej zmianę o wymiarach $21 \times 18 \times 18 \mathrm{~mm}$ poszerzającą asymetrycznie siodło tureckie, rozciągającą się w kierunku lewej zatoki jamistej, z cechami jej naciekania, wskazującą na obecność u pacjenta makrogruczolaka przysadki (ryc. 1). Jednocześnie stężenie prolaktyny w surowicy przekraczało $2000 \mathrm{ng} / \mathrm{ml}$ (18.04.2017 r.) i dokładne jego oznaczenie nie było możliwe. Pacjent dopytywany o występowanie objawów wskazujących na hiperprolaktynemię, datował ją na czas włączenia leczenia przeciwpsychotycznego.

Niezwłocznie podjęto decyzję o zmianie leczenia na arpiprazol (20.04.2017-8.06.2017 r.) w dawce maksymalnej $30 \mathrm{mg}$, co wiązało się ze zmniejszeniem stężenia prolaktyny do 753,95 ng/ml (8.05.2017 r.), ale z pogorszeniem stanu psychicznego. Pacjent odmówił leczenia operacyjnego zaleconego przez konsultującego specjalistę neurochirurga. Endokrynolog zaproponował terapię bromokryptyną, jednak jej przewidywany negatywny wpływ na stan psychiczny pacjenta wymusił zrezygnowanie z tej formy terapii. Do leczenia wprowadzono ziprazidon (15.05.2017-29.06.2017) w dawce $160 \mathrm{mg}$ oraz mirtazapinę (2.06.2017-29.06.2017) w dawce $15 \mathrm{mg}$, uzyskując poprawę stanu psychicznego i spadek stężenia prolaktyny do $1459,52 \mathrm{ng} / \mathrm{ml}$ (26.06.2017). Lekarz endokrynolog podjął próbę leczenia chinagolidem początkowo w dawce $50 \mathrm{mg}$, następnie $75 \mathrm{mg}$ na dobę, jednak przy próbie podwyższania dawki dochodziło do nasilenia objawów psychotycznych. Zdecydowano o zastosowaniu minimalnej dawki podawanej co drugi dzień, co spowodowało dalsze niewielkie obniżenie stężenia prolaktyny.

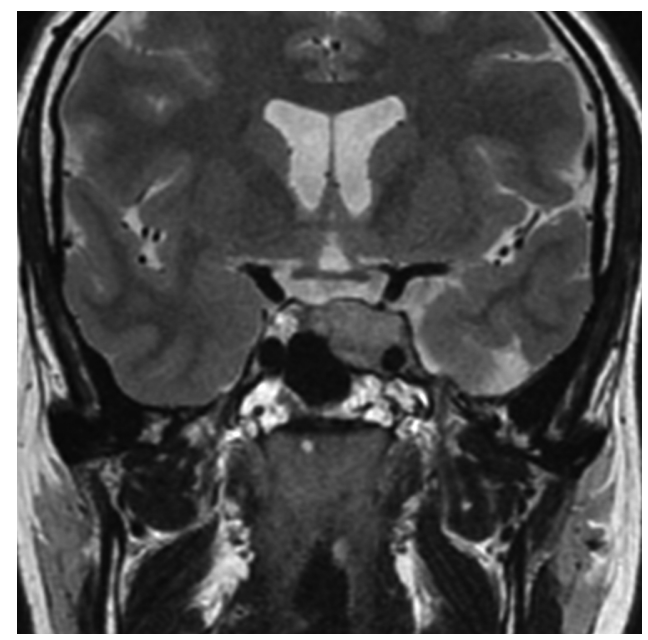

Rycina 1 Z przysadką mózgową od strony lewej związana jest lita, wzmacniająca się masa patologiczna o wymiarach $21 \times 18 \times 18 \mathrm{~mm}$, poszerzająca asymetrycznie siodło tureckie, rozciągająca się $w$ kierunku lewej zatoki jamistej, z cechami jej naciekania. Nie stwierdza się ucisku na skrzyżowanie wzrokowe oraz nerwy wzrokowe w odcinku wewnątrzczaszkowym. Obraz MRI T-2 zależny sugeruje makrogruczolaka przysadki

W kwietniu 2018 roku wykonano kontrolne badanie MRI głowy, które wskazało na nieznaczne zmniejszenie gruczolaka $(21 \times 18 \times 15 \mathrm{~mm})$. Wyniki prolaktyny utrzymywały się na poziomie około $1250 \mathrm{ng} / \mathrm{ml}$. W czerwcu 2018 roku pacjent skarżył się na uczucie napięcia wewnętrznego, problemy z zasypianiem oraz pojedyncze przeżycia psychotyczne w ciągu ostatnich kilku miesięcy. Zaproponowano kontynuację dotychczasowego leczenia, z dołączeniem akceptowalnej przez pacjenta niewielkiej dawki klozapiny (50 mg) oraz rozpoczęcie psychoterapii poznawczo-behawioralnej, co przyniosło pozytywne efekty terapeutyczne. W styczniu 2019 roku wykonano kontrolne badania stężenia prolaktyny i MRI głowy, obserwując dalszą niewielką poprawę w zakresie obniżenia się poziomu prolaktyny (715 ng/ml) oraz brak zmian w MRI w porównaniu z poprzednim badaniem.

\section{Dyskusja}

Celem pracy było, na podstawie opisu przypadku, przedstawienie istotnych problemów diagnostyczno-terapeutycznych związanych ze współwystępowaniem zaburzeń psychotycznych i makrogruczolaka przysadki. 


\section{Konieczność wykonywania rutynowych badań obrazowych w przypadku pacjentów z pierwszym epizodem psychozy}

Mimo iż w przypadku wykonywania rutynowych badań obrazowych mózgu liczba wykrywanych poważnych nieprawidłowości jest niska (0-1\%) (Williams i wsp., 2014), to wykrycie ewentualnych zmian może mieć decydujące znaczenie w prawidłowym postępowaniu leczniczym (Karakuła-Juchnowicz i wsp., 2018). Obecnie nie ma zgodności co do konieczności wprowadzenia tego typu badań do rutynowego postępowania.

Zgodnie z wynikami przeglądu systematycznego Forbes i wsp. (2019) nie ma dowodów na to, że diagnostyka obrazowa mózgu powinna zostać włączona do rutynowych badań diagnostycznych w pierwszym epizodzie psychotycznym, o ile nie stwierdza się współwystępowania zaburzeń neurologicznych lub poznawczych. Procedura w kierunku uszkodzeń centralnego układu nerwowego powinna opierać się na analizie choroby pacjenta, ocenie stanu psychicznego oraz neurologicznego. W przypadku podejrzenia patologii wewnątrzczaszkowej należy wykonać badanie obrazowe za pomocą rezonansu magnetycznego lub tomografii komputerowej. W innych przypadkach należy kierować się opartymi na dowodach naukowych wytycznymi krajowymi (Forbes i wsp., 2019).

Wytyczne American Psychiatric Association (APA, 2010) dotyczące leczenia pacjentów ze schizofrenią podają, że obrazowanie rezonansem magnetycznym czy wykonanie tomografii komputerowej w przypadku pacjentów z pierwszym epizodem psychotycznym albo nietypowym obrazem klinicznym mogą dostarczyć pomocnych informacji w kontekście doprecyzowania diagnozy, ustalenia leczenia i rokowania. Mając na uwadze subtelność zmian neuropatologicznych w przypadku schizofrenii, rezonans magnetyczny jest lepszym wyborem niż tomografia komputerowa (APA, 2010).

Australian Clinical Guidelines for Early Psychosis, czyli wytyczne National Centre of Escellence in Youth Mental Health (Orygen) zalecają wykonanie MRI wszystkim pacjentom z pierwszym epizodem psychotycznym (Orygen, 2016).

Według wytycznych Royal Australian and New Zealand College of Psychiatrists dotyczących postępowania w schizofrenii i zaburzeniach pokrewnych, opinia ekspertów w kwestii zasadności wykonywania badań neuroobrazowych w pierwszym epizodzie psychozy jest podzielona (Galletly i wsp., 2016).

Wytyczne National Institute for Health and Care (NICE) dotyczące neuroobrazowania strukturalnego w psychozie pierwszego epizodu utrzymują stanowisko, iż strukturalne techniki neuroobrazowania nie są zalecane jako rutynowa część badań wstępnych w leczeniu pierwszego epizodu psychozy (NICE, 2011).

Canadian Guidelines for the Assessment and Diagnosis of Patients with Schizophrenia Spectrum and Other
Psychotic Disorders zalecają wykonanie badań neuroobrazowych zarówno w przypadku występujących dodatkowo nieprawidłowości w badaniu neurologicznym, neuropsychologicznym, jak i na podstawie określonych aspektów historii choroby pacjenta (Addington i wsp., 2017).

Od kilku lat oceny badań obrazowych w Polsce są względnie niskie (Agencja, 2016), dlatego też wydaje się zasadne rozważenie ich rutynowego wykonywania u osób z pierwszym epizodem psychozy.

W przypadku omawianego pacjenta, wykonanie MRI głowy w momencie rozpoczęcia leczenia przeciwpsychotycznego dawałoby szansę na wczesną diagnostykę zmian patologicznych w przysadce, zakładając, iź proces ten rozpoczął się przed wystąpieniem objawów psychotycznych. W przypadku rozwoju guza w okresie późniejszym jego wynik mógłby stanowić punkt odniesienia dla kolejno wykonywanych badań kontrolnych.

\section{Potrzeba wykonywania okresowych badań stężenia prolaktyny w przypadku stosowania leków przeciwpsychotycznych}

Nowotwory przysadki i okolicy siodła tureckiego stanowią około $15 \%$ nowotworów wewnątrzczaszkowych u osób dorosłych (Syrenicz, 2009; Mete i Lopes, 2017). Większość z nich to gruczolaki o łagodnym charakterze, przebiegu i dynamice wzrostu (Petersenn, 2019). Gruczolaki przysadki dzieli się ze względu na ich wielkość oraz czynność hormonalną i wynik barwienia immunohistochemicznego (Molitch, 2017). Częściej występują guzy hormonalnie aktywne niż nieaktywne - stanowią one najczęstszą przyczynę nadczynności przysadki (Maitra, 2014; Mehta i Lonser, 2017). Guz prolaktynowy jest najczęstszym typem gruczolaka przysadki (40-57\% przypadków) (Daly i wsp., 2006, Fernandez 2010 i wsp., Lake i wsp., 2013). Objawy guza wynikają z samej wielkości guza - tak zwanego efektu masy (Hardy i Czepko, 1999; Maitra, 2014; Chanson i Maiter, 2019), jak i jego czynności hormonalnej. W przypadku guza prolaktynowego mamy do czynienia $\mathrm{z}$ hiperprolaktynemią powodującą u kobiet: zaburzenia miesiączkowania, mlekotok, zmniejszenie libido, niepłodność, hipogonadyzm, a u mężczyzn: zmniejszenie libido, ginekomastię, zaburzenie wzwodu i erekcji, hipogonadyzm. U obu płci prowadzi do zmniejszenia masy kostnej i jest czynnikiem rozwoju osteoporozy (Matsuyama i wsp., 2003). Nieprawidłowe wysokie stężenie prolaktyny ma również wpływ na stan psychiczny, powodując niepokój, napięcie czy stany depresyjne (Syrenicz, 2009; Liao i Bai, 2014). Współistnienie gruczolaka przysadki u pacjenta z zaburzeniami psychotycznymi wymaga szczególnej uwagi. W takim przypadku nieodzowne wydaje się skrupulatne monitorowanie badań laboratoryjnych oraz dokładna kontrola stężenia prolaktyny prowadzona zgodnie z rekomendacjami dotyczącymi stosowania leków przeciwpsychotycznych. 
Według zaleceń konsultanta krajowego w dziedzinie psychiatrii w sprawie stosowania leków przeciwpsychotycznych II generacji (Zalecenia, 2012), zastosowanie w leczeniu zaburzeń psychotycznych amisulprydu i risperidonu wiąże się z koniecznością monitorowania stężenia prolaktyny podczas leczenia. Badania laboratoryjne, które rekomenduje się wykonać przed włączeniem każdego leku przeciwpsychotycznego, obejmują: morfologię krwi, aktywność transaminazy asparaginowej i alaninowej, poziom bilirubiny, poziom kreatyniny, stężenie elektrolitów, glikemię na czczo oraz lipidogram na czczo. Tylko w uzasadnionych przypadkach zaleca się oznaczenie stężenia prolaktyny oraz hormonów tarczycy (TSH, FT4) przed rozpoczęciem leczenia.

Ważne jest, aby w swojej praktyce klinicznej lekarz pamiętał o zebraniu wywiadu w kierunku hiperprolaktynemii, a także prowadził dokumentację medyczną, która zawiera dokładne adnotacje dotyczące monitorowania wyników badań laboratoryjnych, szczególnie w przypadku stosowania leków, które mają wpływ na szlak guzkowo-lejkowy. Niedopełnienie powyższych może nieść za sobą poważne konsekwencje dla zdrowia i życia pacjenta. W przytoczonym przypadku pacjent podczas ośmioletniego okresu leczenia ambulatoryjnego olanzapiną pozostawał bez monitorowania badań laboratoryjnych, w tym stężenia prolaktyny. W związku z tym, jeden z prawdopodobnych scenariuszy zakłada utrzymywanie się wysokich stężeń prolaktyny w surowicy krwi, co mogłoby prawdopodobnie przyczynić się do rozwoju makrogruczolaka przysadki. Olanzapina jest lekiem przeciwpsychotycznym, który nie wpływa znacząco na poziom prolaktyny w surowicy krwi, choć pojawiają się opisy przypadków, w których wystąpiły objawy związane z wysokim stężeniem prolaktyny w surowicy krwi po rozpoczęciu leczenia olanzapiną (Barata i wsp., 2019).

Trudno bez monitorowania poziomu prolaktyny ustalić, w którym momencie doszło do hiperprolaktynemii, choć z uzyskanego od pacjenta wywiadu dotyczącego wystąpienia objawów ubocznych ze sfery seksualnej można wnioskować, że nastąpiło to po włączeniu do leczenia olanzapiny. Nie można także potwierdzić lub wykluczyć związku przyczynowo-skutkowego między wieloletnim przyjmowaniem olanzapiny a rozwojem makrogruczolaka przysadki. Niemniej, zachowanie większej czujności w zakresie oceny występowania objawów ubocznych i wykonanie okresowego badania poziomu prolaktyny u opisywanego pacjenta mogłoby doprowadzić do wcześniejszego rozpoznania czynnego hormonalnie guza przysadki i zmiany leku przeciwpsychotycznego.

\section{Wybór najbezpieczniejszej formy terapii w przypadku występowania zaburzeń psychotycznych i czynnego makrogruczolaka przysadki}

Gruczolak przysadki mózgowej wydzielający prolaktynę jest najczęstszym guzem przysadki (Lake i wsp., 2013), a w jego leczeniu farmakologicznym stosuje się agonistów dopaminy, które jako efekt uboczny mogą wywoływać objawy psychotyczne. $Z$ drugiej strony, stosowanie leków przeciwpsychotycznych może wiązać się ze zwiększonymi stężeniami prolaktyny w surowicy krwi i objawową hiperprolaktynemią (Ali i wsp., 2010). Taka koincydencja zaburzeń implikuje trudności terapeutyczne i wymaga dokonania umiejętnego doboru strategii leczenia. Oprócz leczenia farmakologicznego, alternatywnym działaniem jest chirurgiczne usunięcie gruczolaka przysadki (Mehta i Lonser, 2017). W przypadku, kiedy zarówno agoniści dopaminy, jak i zabieg chirurgiczny nie są wystarczające do stabilizacji masy guza, można rozważyć radioterapię. Jest ona jednak zarezerwowana tylko dla guzów agresywnych, ponieważ może prowadzić do niedoczynności wydzielniczej przysadki. Ponadto, jej działanie nie wykazuje zadowalających wyników w kontekście normalizacji poziomu prolaktyny w surowicy krwi (Li i wsp., 2017).

W przypadku pacjenta, u którego jednocześnie stwierdza się objawy schizofrenii i aktywnego hormonalnie gruczolaka przysadki, decyzja co do postępowania powinna zostać podjęta w zespole, w skład którego wchodziłby psychiatra, endokrynolog, a także neurolog czy neurochirurg. Należy brać pod uwagę lokalizację, konsekwencje endokrynologiczne oraz efekt masy guza. Wielkość i efekt masy guza mogą stanowić czynniki decydujące o podjęciu leczenia chirurgicznego (Mehta i Lonser, 2017). Nie zaleca się stosowania agonistów dopaminy w przypadku pacjentów, u których występują zaburzenia psychotyczne, ponieważ stwarzają one zagrożenie dekompensacji psychiatrycznej (Robbins i wsp., 1984). W przypadku guzów niemanifestujących się przez efekt masy, postępowaniem może być włączenie hormonów steroidowych i monitorowanie wielkości gruczolaka (Miller 2004). Takie postępowanie ma miejsce u pacjentów z mikrogruczolakami przysadki (Vallette i wsp., 2009). Podjęcie próby leczenia agonistą dopaminy może być przeprowadzone w przypadkach, kiedy pacjent otrzymuje jednocześnie lek przeciwpsychotyczny, jednak nie jest to wystarczające zabezpieczenie przed wystąpieniem dekompensacji psychiatrycznej. Istnieją doniesienia o wystąpieniu objawów psychotycznych na skutek stosowania agonistów dopaminy w połączeniu z lekami przeciwpsychotycznymi (Robbins i wsp., 1984).

Profil leku przeciwpsychotycznego jest ważnym aspektem, który powinno się brać pod uwagę, włączając leczenie farmakologiczne. Wszystkie leki przeciwpsychotyczne mogą do pewnego stopnia wpływać na stężenie prolaktyny w surowicy krwi (Chen i wsp., 2009). Do tych, które znacząco zwiększają jej stężenie podczas leczenia, zalicza się typowe leki przeciwpsychotyczne i risperidon. Klozapina, olanzapina, kwetiapina, aripiprazol i ziprasidon posiadają mniejszy potencjał indukcji hiperprolaktynemii (Byerly i wsp., 2007, Samperi i wsp., 2019). Dowiedziono, że klozapina stosowana w dawkach 
od 125 do 600 mg wykazuje od 20 do $67 \%$ wysycenia receptorów D2. Taki wynik jest równoznaczny z zajęciem receptora D2, poniżej progu wywołującego objawy hiperprolaktynemii. Na tej podstawie można oczekiwać, że stosowanie klozapiny wiąże się z mniejszym ryzykiem podwyższenia stężenia prolaktyny w surowicy krwi (Farah, 2013). Literatura przedmiotu wskazuje szczególnie na dwa leki przeciwpsychotyczne, które nie wpływają lub w minimalny sposób wpływają na stężenie prolaktyny - aripiprazol i ziprazidon (Szarfman i wsp., 2006). Najwięcej doniesień dotyczy zastosowania aripiprazolu w podobnych przypadkach klinicznych (Freeman i wsp., 2007; Steinhagen, 2007; Bakker i wsp., 2016). Na przykład Broekhof i wsp. (2012), dokonując zmiany terapii $\mathrm{z}$ risperidonu na aripiprazol przy jednoczesnym leczeniu kabergoliną, uzyskali remisję schizofrenii, zmniejszenie masy guza i normalizację poziomu prolaktyny. W związku z tym, u naszego pacjenta początkowo włączono do leczenia aripiprazol. Doszło jednak do pogorszenia stanu psychicznego. Do tej pory opublikowano kilkadziesiąt opisów przypadków pogorszenia stanu psychicznego po włączeniu do leczenia aripiprazolu (Grover i wsp., 2006; Ahuja i Lloyd, 2007; Takeuchi i Remington, 2013; Eatt i Varghese, 2014). Możliwe, że to ryzyko jest związane z jego ago-antagonistycznym działaniem na receptory D2 (Stahl, 2009; Takeuchi i Remington, 2013). Mimo poprawy parametrów hormonalnych, stan psychiczny chorego uległ pogorszeniu. W związku z tym odstawiono aripiprazol i włączono ziprasidon. Stan psychiczny się poprawił. Stężenie prolaktyny utrzymywało się na wysokim poziomie, co mogło mieć dodatkowy wpływ na stan psychiczny pacjenta (Syrenicz, 2009; Liao i Bai, 2014).

Biorąc pod uwagę stosowanie agonistów dopaminy należy zwrócić uwagę na badanie Melkersson i Hulting (2000), w którym autorki powołują się na dowody, że chinagolid przenika przez barierę krew-mózg w mniejszym stopniu niż bromokryptyna i będzie wywierać znaczny wpływ na przysadkę, natomiast mniejszy na stan psychiczny. Bromokryptyna natomiast charakteryzuje się bardziej nieselektywnym profilem receptora niż chinagolid, dlatego też ten stosunkowo selektywny agonista receptora D2 może być bardziej korzystnym wyborem leczenia u pacjenta z gruczolakiem przysadki, u którego występują także zaburzenia psychotyczne. W opisanym przez nas przypadku nie zdecydowano się na podawanie bromokryptyny ze względu na występowanie nasilonych objawów psychotycznych. W okresie późniejszym do leczenia włączono chinagolid w niskich dawkach akceptowanych przez pacjenta.

Wydaje się, że u tego typu pacjentów leczeniem z wyboru mogłaby być interwencja chirurgiczna, co też zalecił konsultujący specjalista neurochirurg. Jednak pacjent nie wyraził zgody na zabieg operacyjny. Decyzja pacjenta z całą pewnością wynikała po części ze stanu psychicznego. Z drugiej strony, przy tej wielkości guza ryzyko wznowy po interwencji chirurgicznej jest wysokie i wykonanie resekcji nie gwarantuje sukcesu (Castinetti i wsp., 2009; Farah, 2013). Zdecydowano się na włączenie do leczenia niewielkich akceptowalnych przez pacjenta dawek klozapiny i oddziaływań psychoterapeutycznych, co pozwoliło na uzyskanie dobrej remisji stanu psychicznego.

\section{Wnioski}

Przedstawiony przypadek wskazuje na potrzebę:

1) przeprowadzania rutynowych badań obrazowych w ramach procedur diagnostycznych i epizodu psychotycznego;

2) wykonywania systematycznych badań stężenia prolaktyny w osoczu nie tylko $\mathrm{w}$ trakcie farmakoterapii risperidonem i amisulprydem, ale również podczas leczenia innymi lekami przeciwpsychotycznymi II generacji;

3) wczesnej i ścisłej współpracy interdyscyplinarnej w celu wypracowania wspólnej propozycji terapeutycznej w tak trudnych i nietypowych sytuacjach klinicznych.
Conflict of interest and financial support non declared. / Nie zgłoszono konfliktu interesów oraz dofinansowania.

The work described in this article has been carried out in accordance with The Code of Ethics of the World Medical Association (Declaration of Helsinki) for experiments involving humans, EU Directive 2010/63/EU for animal experiments, and Uniform Requirements for manuscripts submitted to biomedical journals. / Treści przedstawione w artykule są zgodne z zasadami Deklaracji Helsińskiej, dyrektywami EU oraz ujednoliconymi wymaganiami dla czasopism biomedycznych.

Authors' contributions / Wkład autorów: $\mathrm{PH}$ - data collection and interpretation, literature search, preparation of the test results for analysis, the test results analysis / zebranie danych i ich interpretacja, zebranie piśmiennictwa, przygotowanie wyników badania do analizy, opracowanie wyników; JM-T conceptual work, critical reviewing / koncepcja i projekt pracy, krytyczne zrecenzowanie pod kątem istotnej zawartości intelektualnej; ES - literature search, data interpretation, critical reviewing / zebranie piśmiennictwa, interpretacja danych, krytyczne zrecenzowanie pod kątem istotnej zawartości intelektualnej; KK - literature search, data interpretation, critical reviewing, preparation of the article for publication / zebranie piśmiennictwa, interpretacja danych, przygotowanie artykułu do publikacji ; AF - literature search, data interpretation, preparation of the article for publication/ zebranie piśmiennictwa, interpretacja danych, przygotowanie artykułu do publikacji; HK-J - conceptual work, acceptacne of the final article version / wkład w koncepcję i projekt pracy, akceptacja ostatecznej wersji do opublikowania 


\section{References / Piśmiennictwo}

1. Addington D, Abidi S, Garcia-Ortega I, Honer WG, Ismail Z. Canadian guidelines for the assessment and diagnosis of patients with schizophrenia spectrum and other psychotic disorders. Can J Psychiatry 2017; 62: 594-603.

2. Agencja Oceny Technologii Medycznych i Taryfikacji. Wydział Taryfikacji. Świadczenia rezonansu magnetycznego finansowane w ramach produktów NFZ z katalogu ambulatoryjnych świadczeń diagnostycznych kosztochłonnych. Raport w sprawie ustalenia taryfy świadczeń nr WT.541.36.2016; http://www.aotm.gov.pl/www/wp-content/uploads/taryfikacja/2016/projekty_taryf/raporty/31/WT_541_36_2016_ RM_Raport_2016.10.21.pdf (last accessed on 3.01.2020).

3. Ahuja N, Lloyd AJ. Aripiprazole and worsening of psychosis: a case report. J Clin Psychiatry 2007; 68: 805-806.

4. Ali S, Miller KK, Freudenreich O. Management of psychosis associated with a prolactinoma: case report and review of the literature. Psychosomatics 2010; 51(5): 370-376.

5. American Psychiatric Association (APA) Practice Guideline for the Treatment of Patients with Schizophrenia, $2^{\text {nd }}$ Edition. APA 2010; https://psychiatryonline.org/pb/assets/ raw/sitewide/practice_guidelines/guidelines/schizophrenia.pdf (last accessed on 8.01.2020).

6. Ayuk J, Stewart PM. Mortality following pituitary radiotherapy. Pituitary 2009; 12(1): 35-39.

7. Bakker IC, Schubart CD, Zelissen PM. Successful treatment of a prolactinoma with the antipsychotic drug aripiprazole. Endocrinol Diabetes Metab Case Rep 2016; 160028. doi: 10.1530/EDM-16-0028.

8. Barata PC, Santos MJ, Melo JC, Maia T. Olanzapine-induced hyperprolactinemia: two case reports. Front Pharmacol 2019; 10: 846.

9. Becker G, Kocher M, Kortmann RD, Paulsen F, Jeremic B, Müller RP et al. Radiation therapy in the multimodal treatment approach of pituitary adenoma. Strahlenther Onkol 2002; 178(4): 173-186.

10. Berinder K, Stackenäs I, Akre O, Hirschberg AL, Hulting AL. Hyperprolactinaemia in 271 women: up to three decades of clinical follow-up. Clin Endocrinol (Oxf) 2005; 63(4): 450-455.

11. Broekhof R, Gosselink MJ, Pijl H, Giltay EJ. The effect of aripiprazole and quinagolide, a dopamine agonist, in a patient with symptomatic pituitary prolactinoma and chronic psychosis. Gen Hosp Psychiatry 2012; 34(2): 209.el-3.

12. Byerly M, Suppes T, Tran QV, Baker RA. Clinical implications of antipsychotic-induced hyperprolactinemia in patients with schizophrenia spectrum or bipolar spectrum disorders. Recent developments and current perspectives. J Clin Psychopharmacol 2007; 27(6): 639-661.

13. Castinetti F, Nagai M, Morange I, Dufour H, Caron P, Chanson $\mathrm{P}$, et al. Long-term results of stereotactic radiosurgery in secretory pituitary adenomas. J Clin Endocrinol Metab 2009; 94(9): 3400-3407.

14. Casulari LA, de Castro LF, Kessler IM, Mendonça IL, de Fátima Magalhães Gonzaga M.

15. Giant cabergoline-resistant prolactinoma in a man who presented with a psychotic episode during treatment: a case report. J Med Case Rep 2019 Jun 16; 13(1): 183.

16. Chanson P, Maiter D. The epidemiology, diagnosis and treatment of Prolactinomas: the old and the new. Best Pract Res Clin Endocrinol Metab 2019; 33(2): 101290.

17. Chen YL, Cheng TS, Lung FW. Prolactin levels in olanzapine treatment correlate with positive symptoms of schizophrenia. Prim Care Companion J Clin Psychiatry 2009; 11(1): 16-20.

18. Daly AF, Rixhon M, Adam C, Dempegioti A, Tichomirowa MA, Beckers A. High prevalence of pituitary adenomas: a cross-sectional study in the province of Liege, Belgium. J Clin Endocrinol Metab 2006; 91(12): 4769-4775.

19. Eatt J, Varghese ST. Worsening of psychosis with aripiprazole. J Neuropsychiatry Clin Neurosci 2014; 26(2): 20.

20. Farah A. Atypicality of atypical antipsychotics revisited. Curr Psychiatry Rev 2013; 9(4): 316-324.

21. Fernandez A, Karavitaki N, Wass JA. Prevalence of pituitary adenomas: a community-based, cross-sectional study in Banbury (Oxfordshire, UK). Clin Endocrinol 2010; 72(3): 377-382.

22. Forbes M, Stefler D, Velakoulis D, Stuckey S, Trudel J-F, Eyre $\mathrm{H}$ et al. The clinical utility of structural neuroimaging in first-episode psychosis: a systematic review. Aust NZ J Psychiatry 2019; 53(11): 1093-1104.

23. Freeman B, Levy W, Gorman JM. Successful monotherapy treatment with aripiprazole in a patient with schizophrenia and prolactinoma. J Psychiatr Pract 2007; 13(2): 120-124.

24. Galletly C, Castle D, Dark F, Humberstone V, Jablensky A, Killackey E et al. Royal Australian and New Zealand College of Psychiatrists clinical practice guidelines for the management of schizophrenia and related disorders. Aust NZ J Psychiatry 2016; 50: 410-472.

25. Gillam MP, Molitch ME, Lombardi G, Colao A. Advances in the treatment of prolactinomas. Endocr Rev 2006; 27(5): 485-534.

26. Grover S, Sharan P, Gupta N. Aripiprazole worsens psychosis: a case report Prim Care Companion J Clin Psychiatry 2006; $8(6): 380-381$.

27. Hardy J, Czepko R. Guzy przysadki in: Zarys neurochirurgii. Ząbek M. (red.), PZWL Warszawa 1999; 81-107.

28. Kahn RS, Fleischhacker WW, Boter H, Davidson M, Vergouwe Y, Keet IP et al. Effectiveness of antipsychotic drugs in first-episode schizophrenia and schizophreniform disorder: an open randomised clinical trial. Lancet 2008; 371(9618): 1085-1097.

29. Karakuła-Juchnowicz H, Morylowska-Topolska J, Juchnowicz D, Korzeniowska A, Krukow P, Rola R. Paranoid syndrome as the first sign of central neurocytoma: a case report. J Psychiatr Pract 2018; 24(5): 359-363.

30. Lake MG, Krook LS, Cruz SV. Pituitary adenomas: an overview. Am Fam Physician 2013; 88(5): 319-327.

31. Laws ER, Sheehan JP, Sheehan JM, Jagnathan J, Jane JA Jr, Oskouian R. Stereotactic radiosurgery for pituitary adenomas: a review of the literature. J Neurooncol 2004; 69(1-3): 257-272.

32. Li X, Li Y, Cao Y, Li P, Liang B, Sun J et al. Safety and efficacy of fractionated stereotactic radiotherapy and stereotactic radiosurgery for treatment of pituitary adenomas: a systematic review and meta-analysis. J Neurol Sci 2017; 372: 110-116.

33. Liao WT, Bai YM. Major depressive disorder induced by prolactinoma - a case report. Gen Hosp Psychiatry 2014; 36(1): 125.e1-2.

34. Maitra A. Przysadka. Układ dokrewny. In: Patologia Robbinsa. Kumar V. (red.), Elsevier Urban \& Partner Wrocław 2014; 770-775.

35. Matsuyama J, Eshima N, Fukunaga T, Hori S, Kobayashi H, Isono M. Various risks of osteoporosis in patients with pituitary adenomas. J Bone Miner Metab 2003; 21(2): 91-97.

36. Mehta GU, Lonser RR. Management of hormone-secreting pituitary adenomas. Neuro Oncol 2017; 19(6): 762-773. 
37. Melkersson K, Hulting AL. Prolactin-secreting pituitary adenoma in neuroleptic treated patients with psychotic disorder. Eur Arch Psychiatry Clin Neurosci 2000; 250(1): 6-10.

38. Mete O, Lopes MB. Overview of the 2017 WHO Classification of Pituitary Tumors. Endocr Pathol 2017; 28(3): 228-243.

39. Miller KK. Management of hyperprolactinemia in patients receiving antipsychotics. CNS Spectr 2004; 9(S7): 28-32.

40. Molitch ME. Diagnosis and treatment of pituitary adenomas: a review. JAMA 2017; 317(5): 516-524.

41. National Centre Of Excellence In Youth Mental Health (Orygen). Australian Clinical Guidelines for Early Psychosis 2016; www.orygen.org.au/Campus/Expert-Network/ Resources/Free/Clinical-Practice/Australian-Clinical-Guidelines-for-Early-Psychosis/Australian-Clinical-Guidelinesfor-Early-Psychosis.aspx?ext (last accessed on 12.01.2020).

42. National Institute for Health and Care Excellence (NICE). Structural Neuroimaging in First-episode Psychosis. NICE 2011; www.nice.org.uk/guidance/ta136/documents/review-decision-june-2011 (last accessed on 15.01.2020).

43. Petersenn S. Management of aggressive pituitary tumors a 2019 update. Horm Metab Res 2019; 51(12): 755-764.

44. Robbins RJ, Kern PA, Thompson TL. Interactions between thioridazine and bromocriptine in a patient with a prolactin-secreting pituitary adenoma. Am J Med 1984; 76(5): 921-923.

45. Samperi I, Lithgow K, Karavitaki N. Hyperprolactinaemia. J Clin Med 2019; 8(12): 2203.

46. Stahl SM. Podstawy psychofarmakologii. Teoria i praktyka Tom II. Via Medica Gdańsk 2009.

47. Steinhagen CK. Normalization of prolactin with aripiprazole in a patient with psychotic depression and a comorbid pituitary microadenoma. Psychosomatics 2007; 48(4): 350-351.

48. Syrenicz A. Endokrynologia w codziennej praktyce lekarskiej. Pomorski Uniwersytet Medyczny Szczecin 2009.

49. Szarfman A, Tonning JM, Levine JG, Doraiswamy PM. Atypical antipsychotics and pituitary tumors: a pharmacovigilance study. Pharmacotherapy 2006; 26(6): 748-758.

50. Takeuchi H, Remington GA. systematic review of reported cases involving psychotic symptoms worsened by aripiprazolein schizophrenia or schizoaffective disorder. Psychopharmacology 2013; 228(2): 175-185.

51. US Food and Drug Administration (FDA). Risperdal FDA label; https://www.accessdata.fda.gov/drugsatfda_docs/label /2009/020272s056,020588s044,021346s033,021444s03lbl. pdf (last accessed on 5.01.2020).

52. Vallette S, Serri K, Rivera J, Santagata P, Delorme S, Garfield $\mathrm{N}$ et al. Long-term cabergoline therapy is not associated with valvular heart disease in patients with prolactinomas. Pituitary 2009; 12(3): 153-157.

53. Webster J, Piscitelli G, Polli A, Ferrari CI, Ismail I, Scanlon MF. A comparison of cabergoline and bromocriptine in the treatment of hyperprolactinemic amenorrhea. Cabergoline Comparative Study Group. N Engl J Med 1994; 331(14): 904-909.

54. Williams SR, Koyanagi CY, Shigemi Hishinuma E. On the usefulness of structural brain imaging for young first episode in patients with psychosis. Psychiatry Res 2014; 224(2):104-106.

55. Zalecenia w sprawie stosowania leków przeciwpsychotycznych II generacji; http://www.fpn.ipin.edu.pl/archiwum/ 2012-zeszyt-1/zalecenia-w-sprawie-stosowania-lekow-przeciwpsychotycznych-ii-generacji.html (last accessed on 15.01.2020). 